\title{
NRegulator ofnuclearsafety
}

\section{RECEIVED

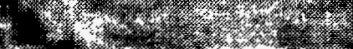 \\ 7. MAY OI 1997

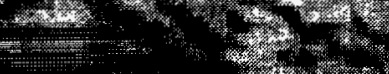

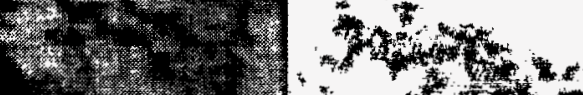 \\ * $77^{2}:$ OSTI

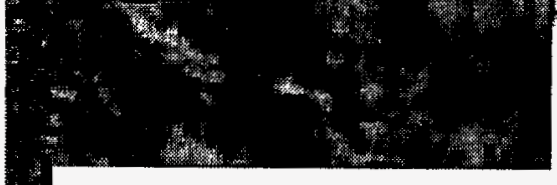

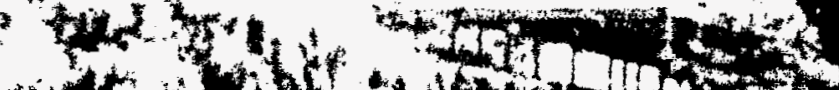

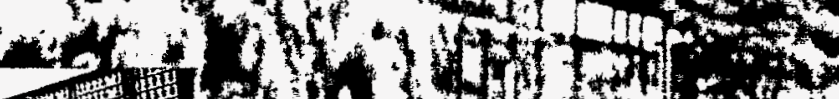

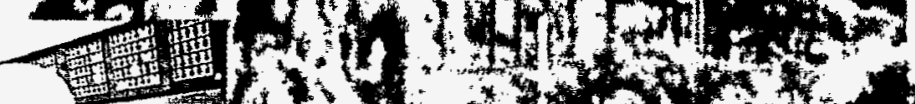
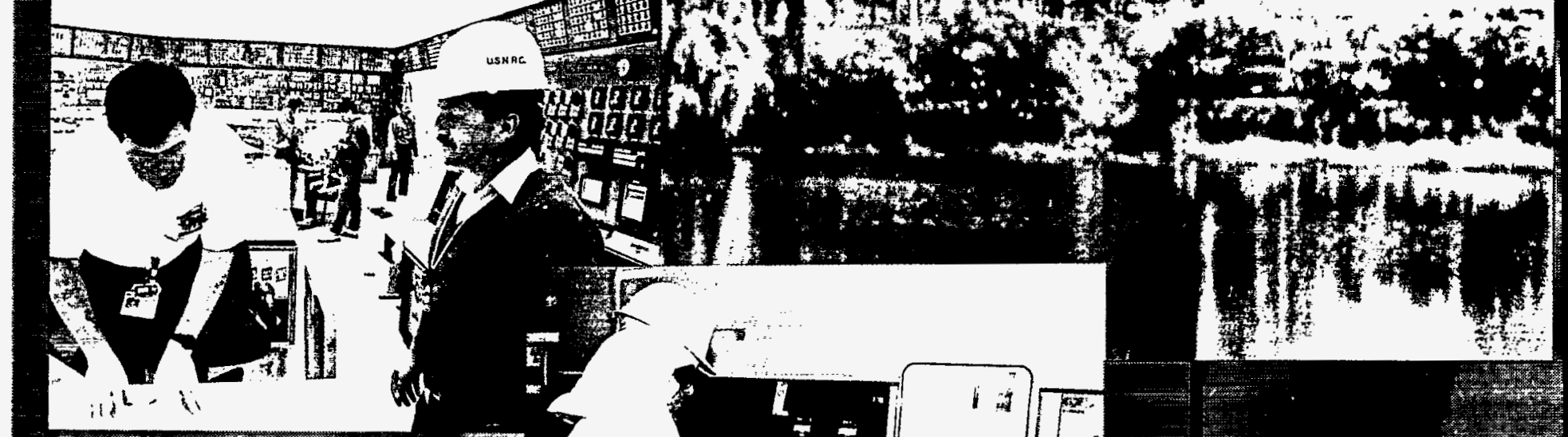

W.
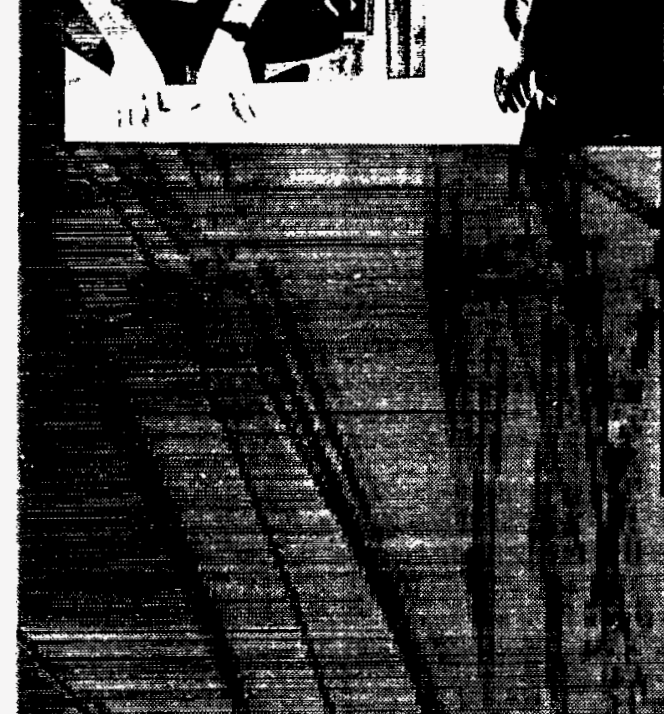

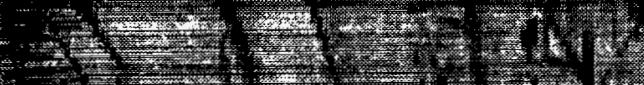 4.t.
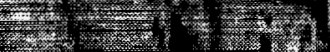

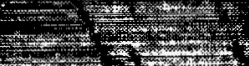

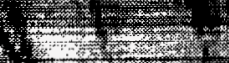 $1+3$

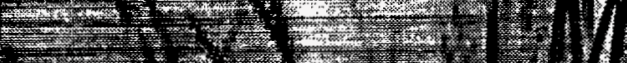

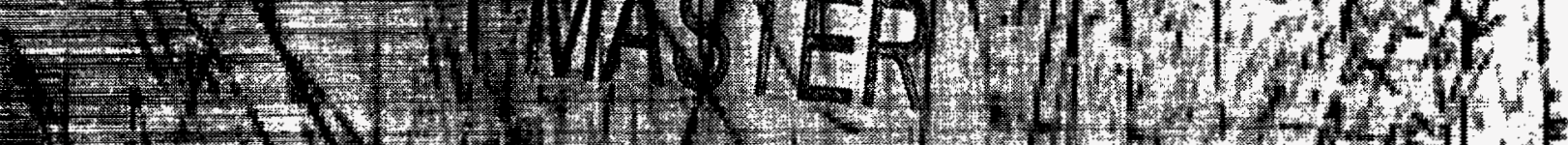

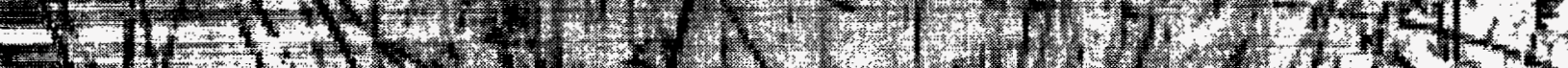

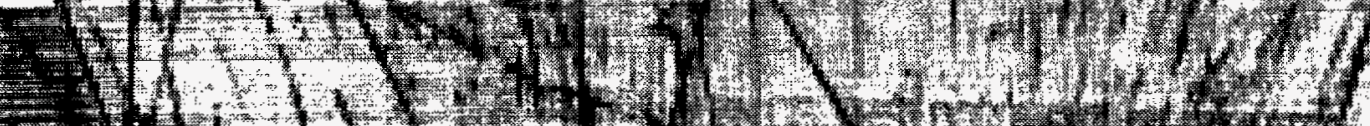

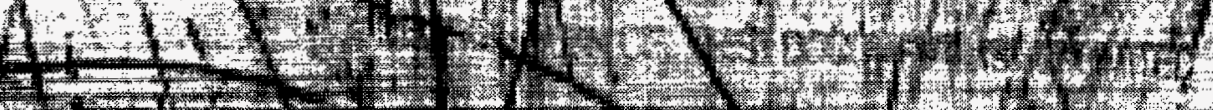

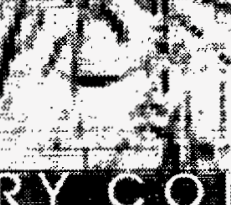

UNITEDISTATES NUGLEAR RE CULA LORY COMMMISSION.

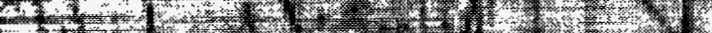




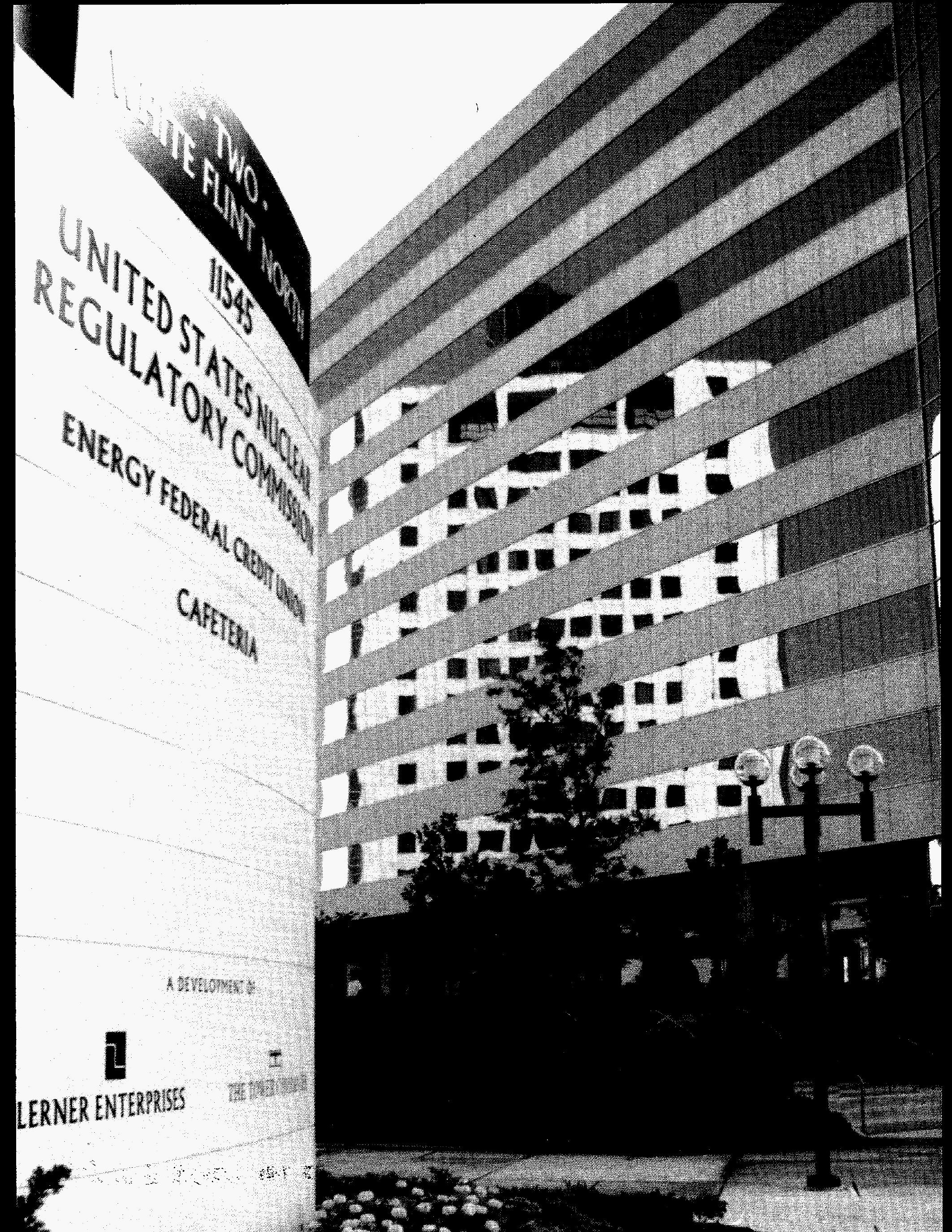




\section{DISCLAMMER}

Portions of this document may be illegible in electronic image products. Images are produced from the best available original document. 


\section{DISCLAIMER}

This report was prepared as an account of work sponsored by an agency of the United States Government. Neither the United States Government nor any agency thereof, nor any of their employees, make any warranty, express or implied, or assumes any legal liability or responsibility for the accuracy, completeness, or usefulness of any information, apparatus, product, or process disclosed, or represents that its use would not infringe privately owned rights. Reference herein to any specific commercial product, process, or service by trade name, trademark, manufacturer, or otherwise does not necessarily constitute or imply its endorsement, recommendation, or favoring by the United States Government or any agency thereof. The views and opinions of authors expressed herein do not necessarily state or reflect those of the United States Government or any agency thereof. 


\section{NRC-REGULATOR OF NUCLEAR SAFETY}

$\mathrm{T}_{\text {he }}$ mission (NRC) was formed in 1975 to regulate the various commercial and institutional uses of nuclear energy, including nuclear power plants. The agency succeeded the Atomic Energy Commission, which previously had responsibility for both developing and regulating nuclear activities. Federal research and development work for all energy sources, as well as nuclear weapons production, is now conducted by the U.S. Department of Energy.

Under its responsibility to protect public health and safety, the NRC has three principal regulatory functions: (1) establish standards and regulations, (2) issue licenses for nuclear facilities and users of nuclear materials, and (3) inspect facilities and users of nuclear materials to ensure compliance with the requirements. These regulatory functions relate to both nuclear power plants and to other uses of nuclear materials - like nuclear medicine programs at hospitals, academic activities at educational institutions, research work, and such industrial applications as gauges and testing equipment.

The NRC places a high priority on keeping the public informed of its work. The agency recognizes the interest of citizens in what it does through such activities as maintaining public document rooms across the country and holding public hearings, public meetings in local areas, and discussions with individuals and organizations.

\section{WHY REGULATE?}

$\mathrm{T}_{\text {he }}$ lated because of the potential hazards involved in using radioactive materials. These radioactive materials give off radiation, which can be hazardous to people if they are exposed to it in significant amounts. The extent of the risk depends on the type and amount of radiation emitted by the radioactive material, the distance between the source of the radiation and a person, and the length of time a person is exposed to the radiation.

The risks can be lessened by reducing any or all of these
People are continuously exposed to radiation from many sourcescosmic radiation from space, radiation from radioactive elements in soil and rock, and radiation from medical and dental $x$-rays and other medical procedures. 
factors. The hazard is less if there is a shielding material like lead or concrete to block some of the radiation, if a person moves farther from the radiation source, or if the exposure time is reduced.

If radioactive materials are properly handled and regulated, they do not pose a significant risk to the public or to workers.

Radioactivity from natural sources is present throughout the world. People are continuously exposed to low-level radiation from radioactive materials in the earth and from cosmic rays from space. Exposure to natural radiation can be affected by geography as well as lifestyle. For example, radiation levels are higher in the mountains, and travel by airplane contributes additional exposure because of increased cosmic radiation at high altitudes. Most people also receive some radiation exposure from medical and dental $x$-rays and other medical procedures. The NRC's regulatory program establishes limits for radiation exposure to workers and the general public as a result of the various uses of radioactive materials licensed by the NRC. In addition, the $N R C$ requires users to take steps to keep exposures well below the limits.

\section{NRC ORGANIZATION}

Tr

Le NRC is headed by a five- member Commission. The Commissioners are appointed to 5-year terms by the President of the United States with confirmation by the Senate. A Chairman is designated by the President.

The NRC staff numbers approximately 3,000 with a budget of about $\$ 500$ million. Roughly two-thirds of the NRC employees work in the agency's headquarters in Rockville, Maryland, or nearby offices. The remainder are located in four regional offices and one field office throughout the country or at resident inspector offices at each commercial nuclear power plant.

\section{NRC REGULATIONS}

$\mathrm{T}$

Ihe NRC sets the rules that users of radioactive materials must follow. These rules are intended to protect the persons using the radioactive materials and the general public from the potential hazards of radioactivity. Many NRC regulations have been established or changed, as necessary, based on the recommendations of the NRC staff. Members of the public and interested organizations can also request changes in regulations. The views of the public, of the industry being regulated, and of other interested parties are usually solicited before new rules or changes are adopted.

\section{REGULATORY RESEARCH}




\section{LICENSES}

Any organization or individual intending to possess or use radioactive materials must obtain a license. The use of very small amounts of radioactive materials - like the tiny radiation source inside many smoke detectors - is exempt from licensing or is authorized by a general license, which does not require active control to assure safety. However, for the manufacturing of these and similar items, a specific license involving regulatory control is required.

Licenses for nuclear power plants and their operators are issued by the NRC. Licenses for other uses of radioactive materials are issued either by the NRC or by State Governments under NRC-approved regulatory programs. About 6,000 licenses for radioactive materials are under the jurisdiction of the NRC, and about 15,500 are under the jurisdiction of those States known as Agreement States that regulate certain radioactive materials under agreements with the NRC.

States also have regulatory jurisdiction over certain radioactive substances that occur naturally (primarily radium and radon) or are produced by machines called particle accelerators.

The NRC or State license specifies the types and quantities of radioactive materials that may be possessed and used, as well as any specific restrictions on their use. Typically, licenses describe the location of use, the training and qualifications of workers, specific procedures for using the materials, and any special safety precautions required. The license holder must follow the specific license requirements as well as the more general NRC regulations.

\section{POWER PLANT LICENSES}

In required two licenses - a construction permit, which allowed the facility to be built, and an operating license, which permitted operation of the facility once it was completed.

In 1989 the NRC adopted a streamlined licensing process that encourages the use of standardized and preapproved designs for any future plant proposals and provides for the issuance of a combined construction permit and operating license. Another feature of the streamlined process is
$N R C$

Headquarters and regional office locations

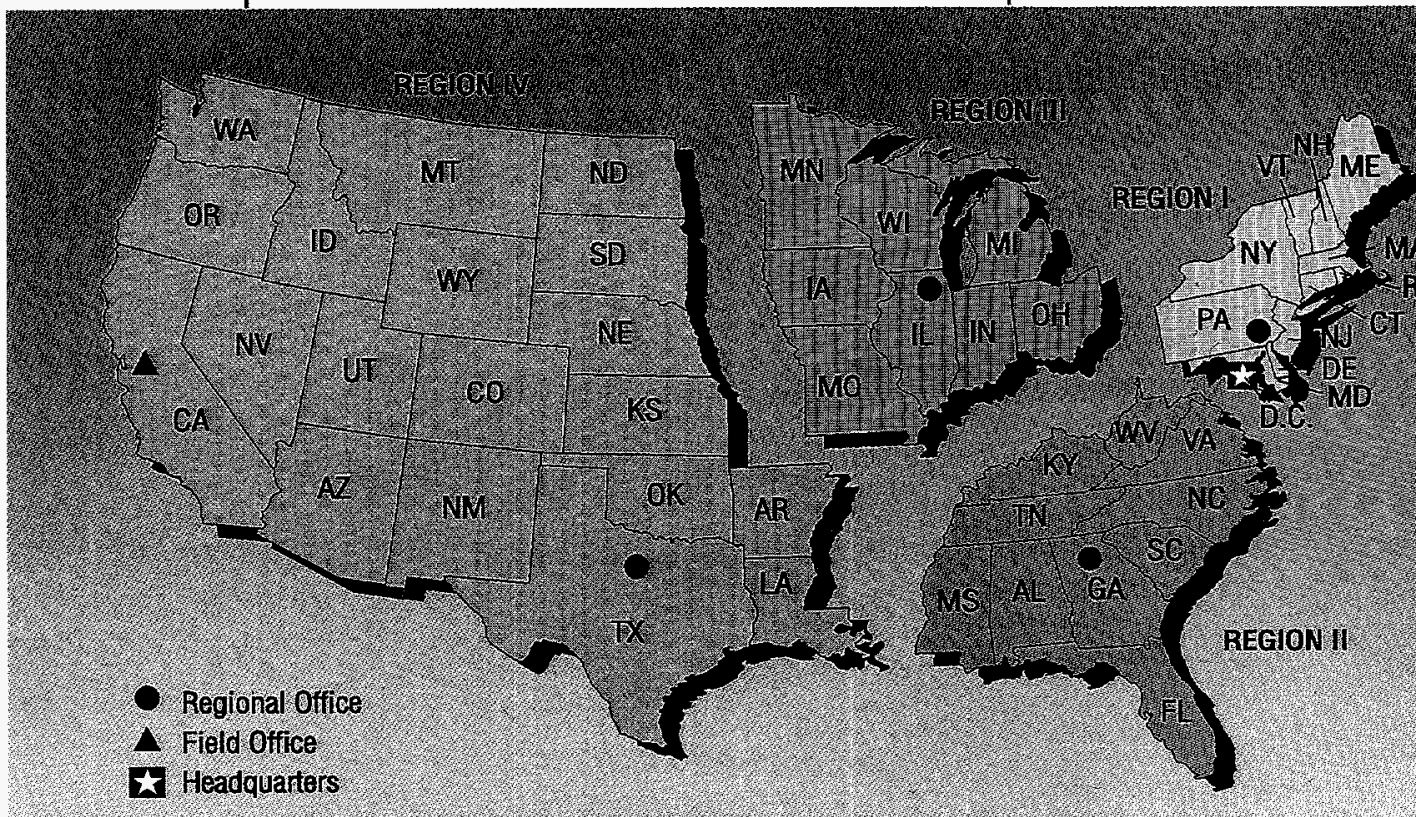

Note: Alaska and Hawail are included in Region IV

\section{3}


possible early approval of sites for nuclear plants. This combined licensing process provides for the early resolution of virtually all issues before construction begins. This combined license also incorporates a program of tests, inspections, and related acceptance criteria that are necessary and sufficient to show that the plant has been properly built. These criteria must be met before operation can begin.

This process provides for public hearings on the certification of the standard design. It also provides for public hearings on the site approval and on the issuance of a combined construction permit and operating license. As the plant nears completion, a public hearing could be held if a significant question exists on whether the criteria of the combined license have been met.

The licenses for nuclear power plants are issued for a 40-year period. Licenses for currently operating plants will begin to expire after the year 2000. The NRC has developed criteria to be used if utilities seek to have the licenses extended.

Licenses for nuclear power plants can be amended and updated as the result of operating experiences at that plant or at other plants. When necessary, the NRC can impose new regulations or require changes in operating procedures or equipment to improve the safety of nuclear power plant operations.

In addition to licensing the facility, the NRC also licenses the individuals who operate the controls of the reactor. Licenses fall into two categories reactor operator and senior reactor operator. The second category is necessary for supervisory positions. Before operator licenses are issued, individuals must complete an extensive training program conducted by the utility and pass license examinations administered by NRC examiners. Once licensed, the operators continue to receive training and are periodically tested to show they remain qualified to operate the plant.

\section{INSPECTIONS}

$\mathrm{T}$

the NRC periodically inspects all facilities it licenses to ensure that their activities meet NRC regulations and the terms of their licenses. These inspections vary in scope and frequency according to the relative hazard of the authorized activities. Throughout the construction period and operating life of a nuclear power plant, for example, numerous inspections are conducted each year. A small medical or research facility, using limited quantities of radioactive materials, might be inspected every few years.

For a nuclear power plant, the NRC inspection program includes the work of NRC resident inspectors, who are stationed at the nuclear plants on a full-time basis; inspections by specialists based in regional offices and NRC headquarters; and special team inspections made up of personnel from the regional offices and from NRC headquarters. Normal inspections consist of examination of a sample of the work being performed by a utility. If evidence of problems is found, the inspector will focus on that work area in more detail.

The core of the NRC inspection program for nuclear power plants is carried out by the resident inspectors; at least two inspectors are assigned to each site. 
The inspection specialists, based in regional offices, review plant security, emergency planning, radiation protection, environmental monitoring, periodic testing of plant equipment and systems, fire protection, construction activities, and other more specialized areas.

During the course of a year, NRC specialists may conduct 10 to 25 routine inspections at each nuclear power plant, depending on the activities at the plants and problems that may occur.

The special team inspections may focus on a specific plant activity, like maintenance or security, or a team may be sent to the plant to look at a specific operating problem or accident.

All inspections and the findings by the inspectors are documented in inspection reports. These reports are sent to the facility to inform the utility of the findings. Inspection reports are also maintained for public review in a public library near each plant site and at the NRC Public Document Room in Washington, D.C. (Certain sensitive information - principally on nuclear facility security - may be withheld from public disclosure.)

When the inspections uncover violations of NRC requirements, the agency has a range of enforcement actions. The basic action is issuance of a notice of violation, which requires the licensee to correct the problem and take steps to prevent a recurrence of the violation. The licensee's response must be acceptable to the NRC.
For more serious violations or repetitive ones, the NRC may fine utilities and other licensees up to $\$ 110,000$ a day for each violation.

If serious questions exist about the safety of NRC-licensed activities, the NRC may issue orders requiring that licensed activities be halted or an individual be removed from work involving NRC-licensed materials. NRC orders also may modify, suspend, or revoke a license.

Licensed activities, if halted, may not be resumed until the safety and management problems are corrected and the NRC approves the resumption of work.

A licensee or individual who chooses to contest a fine or an order has the right to a hearing before the NRC.

The results of the NRC inspection program for each nuclear power plant are periodically compiled with other agency evaluations in a review called a Systematic Assessment of Licensee
NRC resident inspectors are assigned to each nuclear power plant; specialists from NRC regional offices and headquarters conduct additional inspections. 


\section{OTHER USES OF RADIOACTIVE MATERIALS}

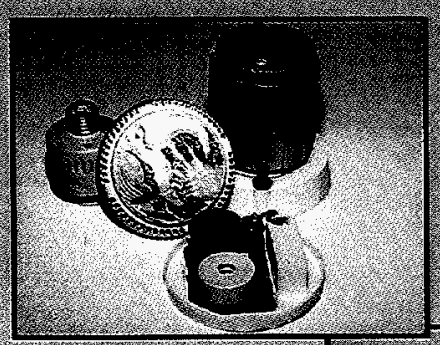

Smoke

Detectors

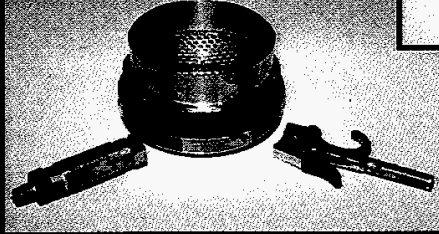

Static Eliminator

Gun \&: Bow Sights

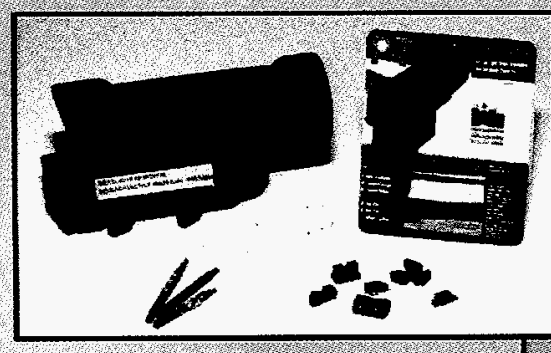

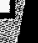
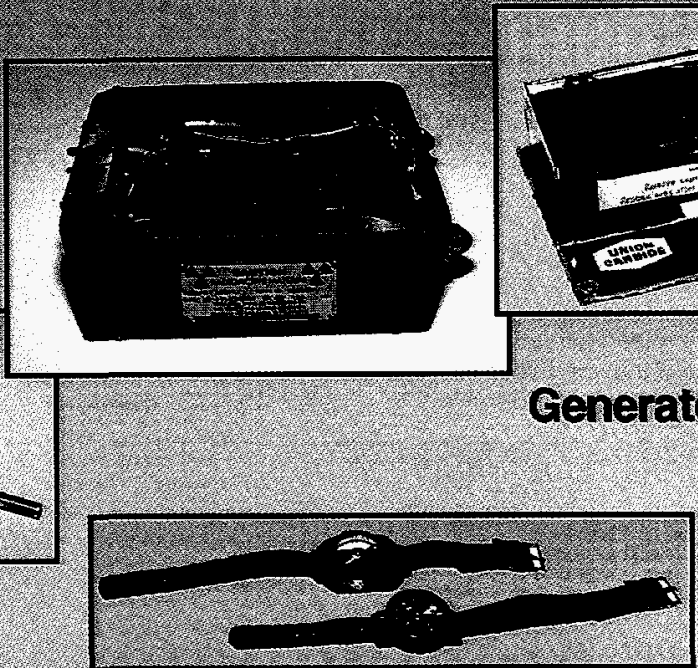

Luminous Watch Dials

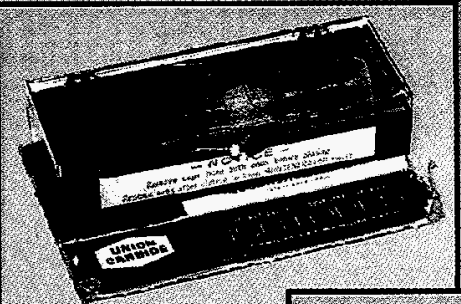

\section{Generators}

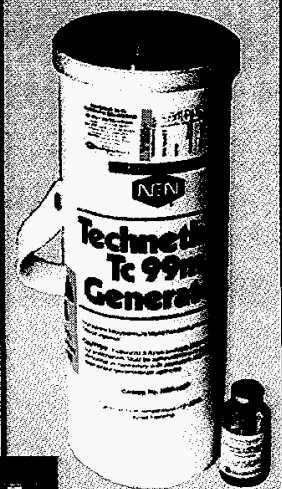

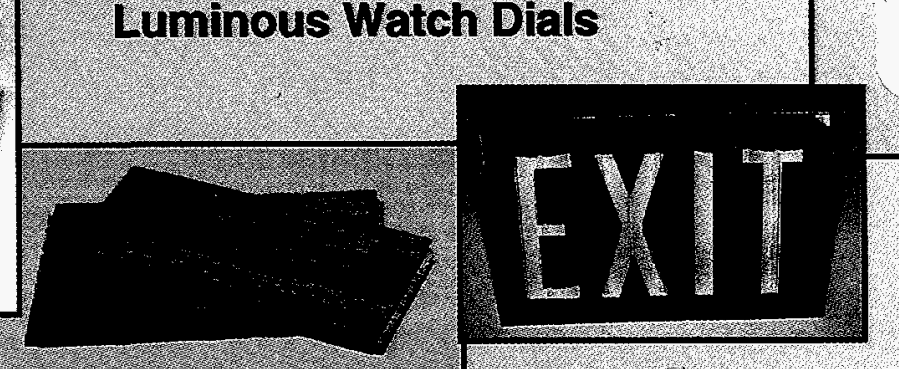

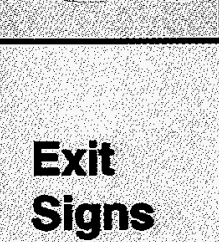

\section{Wood Flooring}

Radioactive materials are used in a wide variety of applications besides fuel for nuclear power plants.

These applications include:

- Medical radiation therapy and diagnostic tests using radioactive pharmaceuticals.

- Consumer products like smoke detectors, "Exit" signs, static elimination devices, and luminous watch dials.

- Wood flooring treated with gamma radiation to resist abrasion, and certain gemstones such as blue topaz

- Industrial radiography, using sealed radiation sources to make $x$-ray-like pictures of heavy metal objects like pipes and valves.

- Other commercial and industrial uses, including testing devices and gauges to measure such characteristics as soil density or levels of a substance in processing equipment.

- Various research activities.
Each of these uses requires an

NRC or Agreement State license, and the activities are periodically inspected by NRC or State personnel. Violations of $N R C$ requirements are subject to the same enforcement options as nuclear power plants, although the level of fines imposed are normally substantially lower. 
Performance (SALP) report. These reports, issued every 12 to 24 months, are public documents and are reviewed with the utility in a meeting open to the public.

On occasion, the NRC receives allegations of wrongdoing involving misconduct by licensees or their contractors. Allegations of possible criminal activities are handled by the professional investigative staff of the NRC Office of Investigations. These investigations may result in civil enforcement action or criminal prosecution against licensees, individuals, or others.

\section{HOW A NUCLEAR POWER PLANT WORKS}

\section{P} energy into another. Electrical generating plants convert heat, the energy of wind or falling water, or solar energy into electricity.

A nuclear power plant is one of those plants that converts heat into electricity. Other types of heat-conversion plants burn coal, oil, or gas for a heat source that is used to produce electricity.

The heat - no matter what the source - is normally used to heat water to the boiling point and produce steam. This steam is then carried by pipes to a turbine - which has a series of fan blades on a shaft. The force of the steam pushes against the blades, turning the turbine.
The turbine is connected to a generator. As the turbine shaft spins, the generator turns and produces electricity. This electricity is then carried by wires to the homes, businesses, and institutions where the electricity is used.

Electricity is one of the few forms of energy that can easily be moved from one place to another. Electrical energy can be produced in large quantities at one location and transported by wires to many different places.

We can see coal, oil, or gas burning - and we know from experience that it produces heat. This is the sort of energy many people use to heat their homes. Some furnaces heat air, which is blown through ducts into each room; others heat water, which is piped throughout the house into radiators where the water gives off some of the heat it absorbed from the burning fuel.

Nuclear energy - as it is used in a nuclear power plant - cannot be seen. There is no burning of fuel in the usual
Energy is released when an atom splits into smaller pieces. These smaller pieces strike other atoms, releasing more energy. This continuous splitting of atoms in a reactor is called chain reaction.

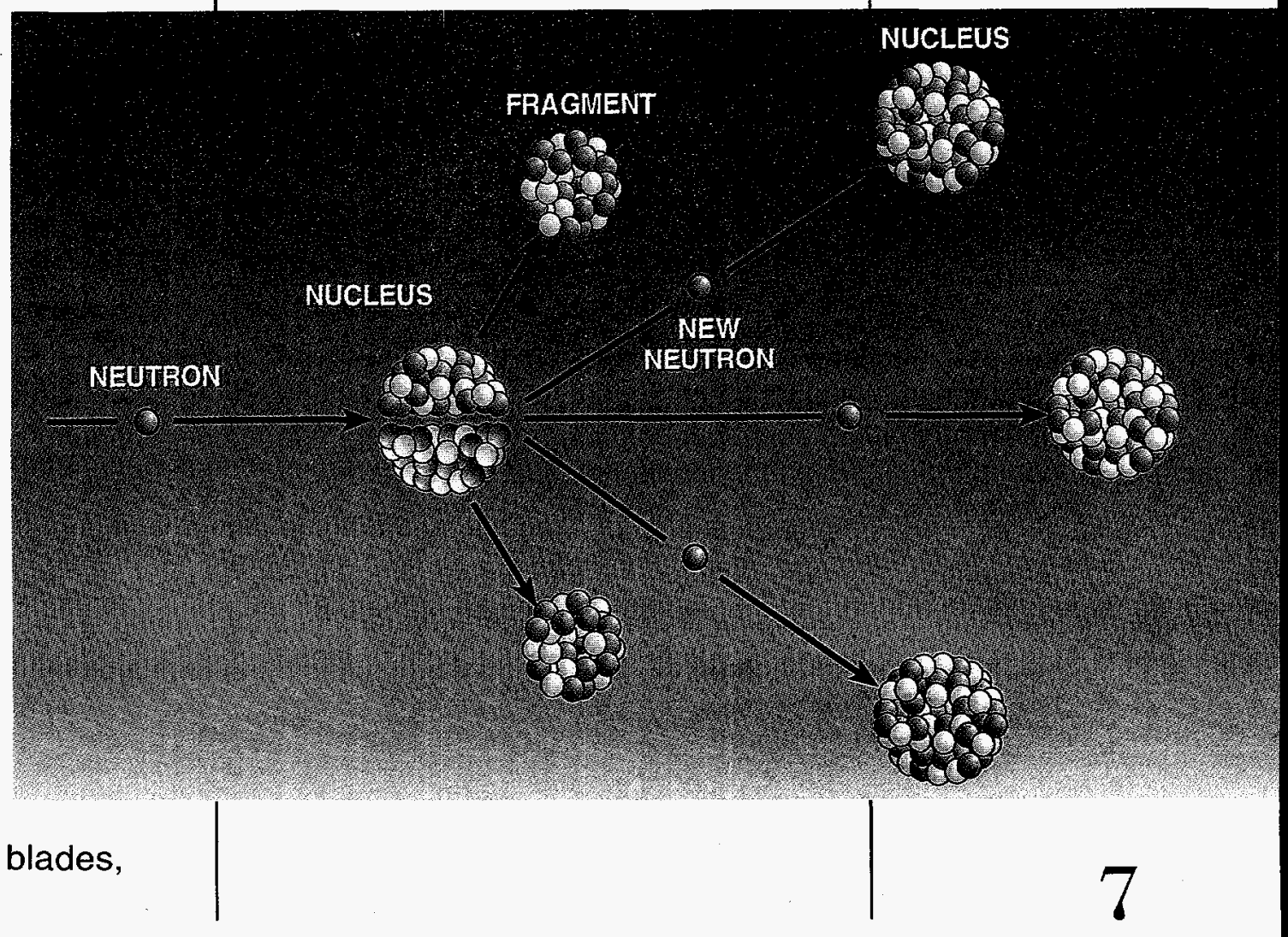


The fuel rods in the reactor contain hundreds of ceramic pellets of uranium fuel. Each rod is sealed to prevent radioactive byproducts from entering the cooling water surrounding the fuel. The fuel rods are grouped into bundles or assemblies. Control rods in the reactor regulate the energy being produced.

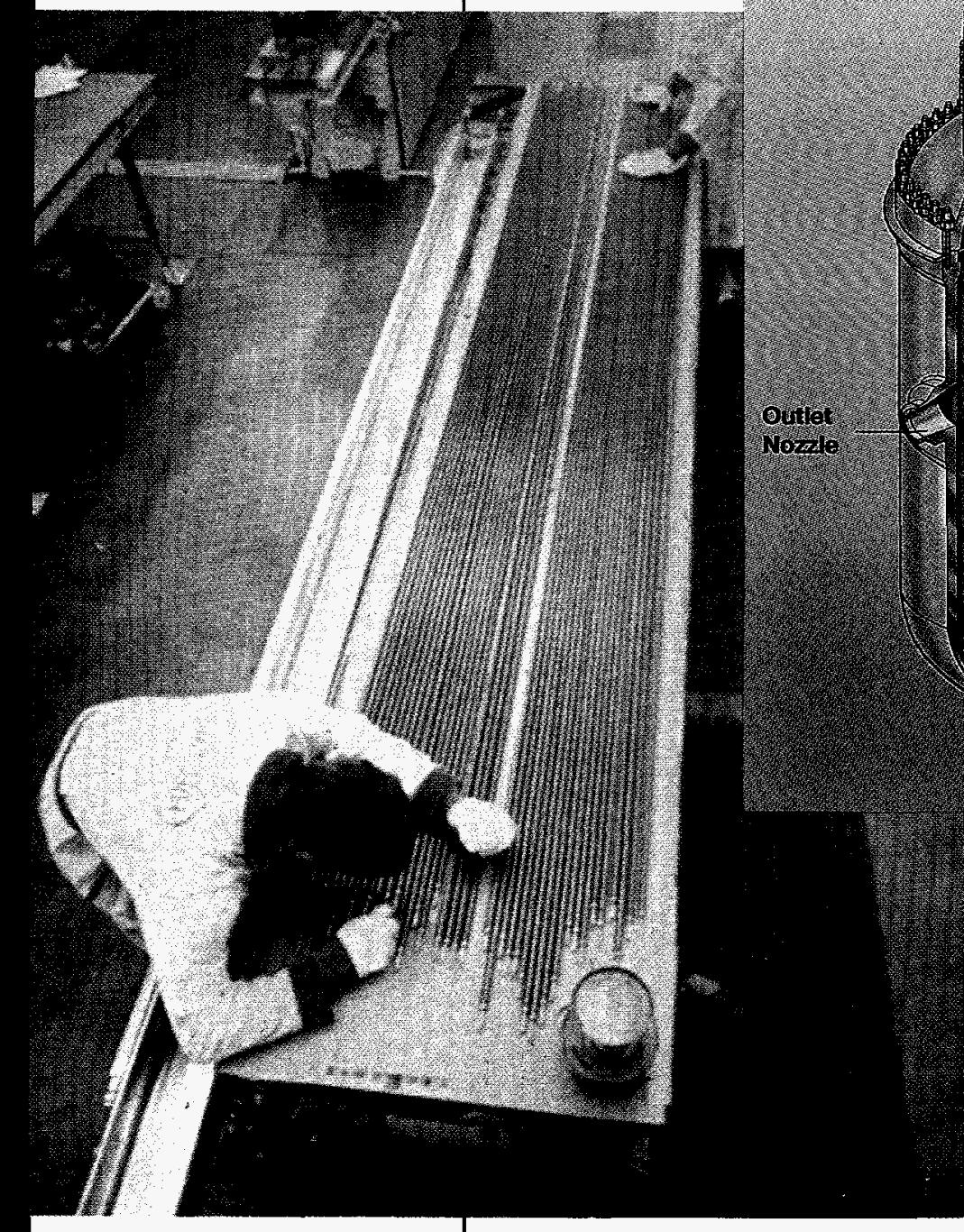

sense. Rather, energy is given off by the nuclear fuel as certain types of atoms split into pieces. This energy is in the form of fast-moving particles and invisible radiation. As the particles and radiation move through the fuel and surrounding water, the energy is converted into heat.

The heat is the useful energy resulting from the splitting of atoms. The radiation energy itself can be hazardous and requires special precautions to protect people and the environment.

To understand this process let's look at a nuclear reactor - which is a large water-filled vessel containing the nuclear fuel.
Water in the reactor is heated by the nuclear reaction - and the heat is carried off to spin the turbine.

\section{URANIUM FUEL}

In nium, but only a certain type of uranium atom can be easily split to produce energy. This type of uranium atom called uranium-235 - is less than 1 percent of uranium as it is mined. To make fuel for reactors, the uranium ore is purified and then processed to increase the percentage of uranium235 to 2 to 4 percent of the uranium. This percentage is enough for a continuous splitting of uranium atoms - but much less than the percentage necessary for a nuclear weapon, which requires almost 100-percent pure uranium-235. The low percentage of uranium235 in reactor fuel is one of the reasons a plant can never explode like an atomic bomb.

Uranium fuel is formed into small cylindrical pellets, each about the size of a finger tip. These pellets are then loaded into metal tubes about 12 feet long. These tubes, called fuel rods, are sealed and grouped into bundles or assemblies. The fuel assemblies are produced at several commercial facilities for shipment to the nuclear plants to be loaded into the reactor.

When a uranium-235 atom splits or "fissions," to use the technical term - it gives off energy in the form of 
radiation and as also fast-moving pieces of the original atom. One of these pieces, which is called a neutron, can collide with another uranium-235 atom and cause it to split, too. A continuing series of these atomic splits, each triggering another one, is called a chain reaction.

Uranium-235 will split, or "fission," spontaneously, but these spontaneous atomic splits aren't frequent or reliable enough to use as an energy source. The pieces fly away too fast and don't cause the fission of another atom. The pieces need to be slowed down so that they can collide with another uranium-235 atom and continue the chain reaction.

Several types of materials can be used to slow down the atomic particles, but most nuclear power plants (including all of those now operating in the United States) use water as the "moderator" - the material that slows down the particles to allow the chain reaction to continue.

To control the chain reaction, reactors have control rods which can be inserted into the reactor to absorb the neutrons as they are given off, thus slowing or stopping the chain reaction.

\section{TWO REACTOR TYPES}

\section{ก}

I wo main types of reactors are in operation in the United States - the pressurized water reactor (PWR) and the boiling water reactor (BWR). About two-thirds of the reactors are PWRs, and one-third are BWRs.

The PWR is a two-stage system that keeps the water in the reactor under high pressure so that it does not boil. Piping carries this heated water to large cylinders called steam generators. The heated reactor water flows through thousands of tubes in the steam generator. The tubes are surrounded by a secondary water supply that boils and produces steam, which is carried away by pipes to spin the turbine generator.

The reactor cooling water then returns to the reactor to be reheated and circulated back to the steam generator, again in a continuous loop.

The BWR is a single-stage system that allows the water in the reactor to boil and produce steam, which is then piped directly to the turbine generator.

In both types of reactors, once the steam loses its energy in spinning the turbine, it flows into a condenser.

Because not all the heat energy in the steam can be converted into electricity, the leftover heat must be carried away by cooling water pumped through the condenser. The condenser contains thousands of tubes carrying cool water, which causes the steam to condense back to water. The water is collected in the condenser and pumped back to be reheated, either in the reactor itself for a BWR or in the PWR steam generator.

The condenser cooling water is drawn from a lake, river, or ocean. This water does not actually pass through the reactor, but only through the condenser tubes to cool the steam after it goes through the turbine. There is no contact between the condenser cooling water and the reactor cooling water or the reactor components themselves.

This outside cooling water, heated as it passes through the condenser, is returned to the source lake, river, or ocean. Many nuclear plants as well as other types of power plants or industrial facilities use cooling towers, 


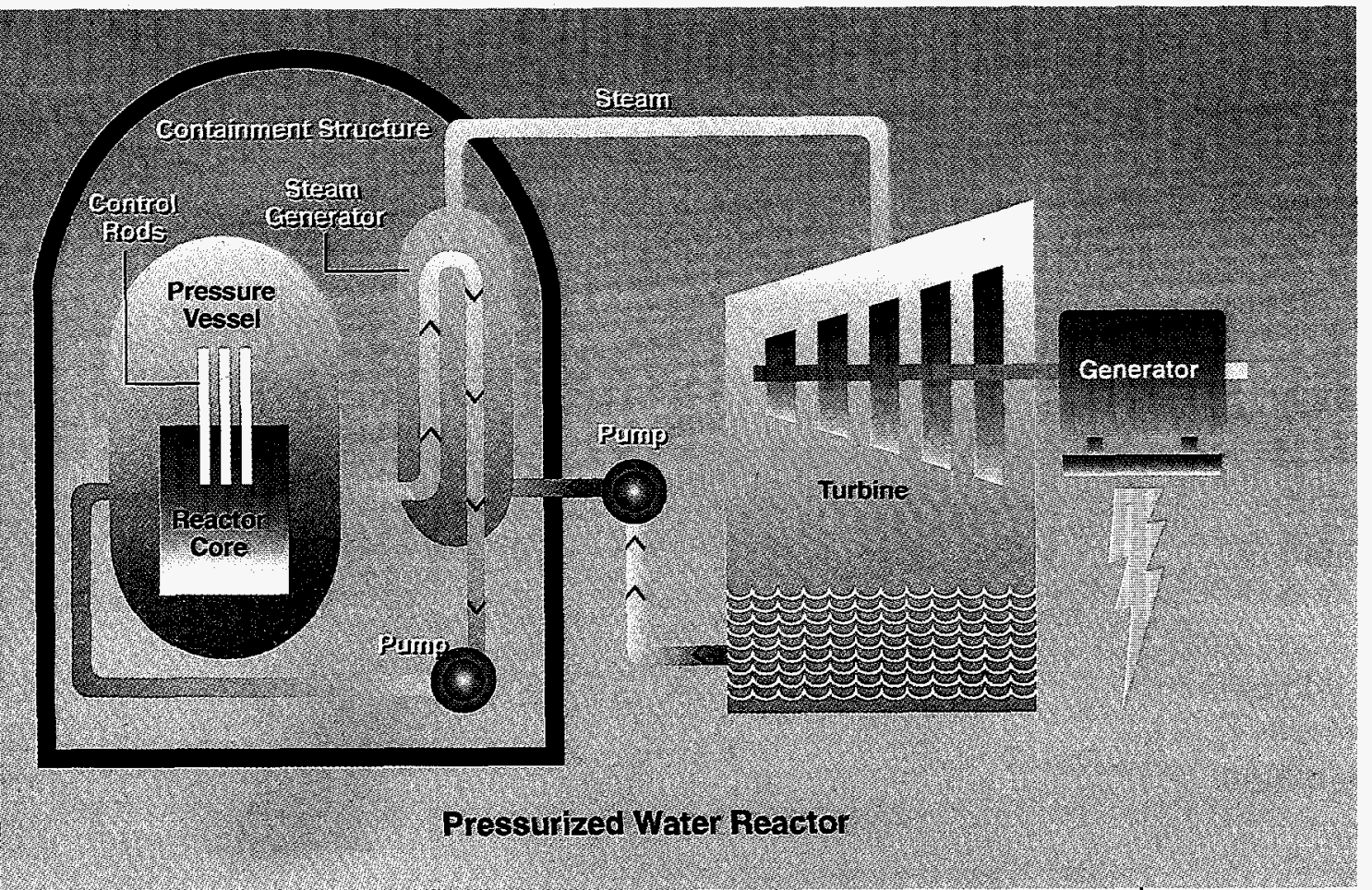

Radioactive materials require careful use because they produce radiation - a form of energy that can damage human cells and, depending on the amount and duration of the exposure, can potentially cause cancer over long periods of time. A person can be exposed to radiation in two ways. Internal exposures occur if a radioactive material is inhaled or ingested and remains deposited in the body. External exposures can result from a person

A pressurized water reactor circulates water through the reactor under pressure. The heated water goes to a large cylinder called a steam generator where it heats another water system to make steam. This steam spins the turbine generator to make electricity. cooling lakes or ponds, or other techniques to reduce the effects of heated water discharged directly back into the river, lake, or ocean. With cooling towers, the water, once cooled, is usually pumped back into the condenser to be used again to carry off heat. Only a small portion of the water is returned to the natural water source.

Once the steam is produced, the process and equipment used to generate electricity are similar in nuclear power plants and fossil-fueled power plants. Fossil-fueled plants also discharge heated water to the environment or use cooling towers or other means to cool the water from the condenser.

\section{RADIOACTIVE BYPRODUCTS}

B produces radioactive materials, which can be hazardous, nuclear power plants are equipped with safety systems to protect workers, the public, and the environment. being close to a radioactive material without adequate shielding.

In the reactor, most of these hazardous radioactive substances called fission byproducts - are trapped in the fuel pellets themselves or in the sealed metal tubes holding the fuel. Small amounts of these radioactive fission byproducts, principally gases, however, become mixed with the water passing through the reactor. Other impurities in the water are also made radioactive as they pass through the reactor. The water is processed and filtered to remove these radioactive impurities and then returned to the reactor cooling system. Small quantities of radioactive gases and liquids are ultimately released to the environment under controlled and monitored conditions.

Radioactive materials lose their radioactive properties over time. Some are short-lived and become nonradioactive forms in seconds or minutes. Other radioactive elements take much longer to lose their radioactivity. This process is called radioactive decay. 
The NRC has established limits for the release of radioactivity during routine operations. These limits are based on guidelines set by the Environmental Protection Agency and by national and international standard-setting groups. Although the effects of very low levels of radiation are difficult to detect, the NRC limits are based on the conservative assumption that radiation exposures to members of the public should only be a small fraction of what they receive from natural environmental radiation.

Experience has shown that nuclear plants typically release only a small portion of the NRC limits during normal operations. A person spending a full year at a nuclear plant boundary would receive an additional radiation exposure of less than 1 percent of the radiation exposure everyone receives from naturally occurring radiation. (Natural environmental radiation exposures average 300 millirems per year.) Yearround exposure at the plant boundary is an additional 1 to 2 millirems or less.

The NRC also sets limits for radiation exposure to individuals working at nuclear plants and other facilities using radioactive materials. Because these individuals receive the radiation exposure as part of their employment and because they receive special training on radiation protection, the occupational limits are higher than those permitted for the general public. Radiation workers must wear devices to measure the radiation to which they are exposed.

The environmental impact of routine operations at a nuclear plant is very small. But because of the radioactivity remaining in the reactor fuel, the plant must have effective safety systems to prevent an accident that would lead to a large amount of that radioactivity being released from the plant. The likelihood of such an accident is remote, but the possibility that one could occur leads to special care in design, construction, and operation of nuclear power plants.

\section{REACTOR SAFETY SYSTEMS}

A with four major types of safety systems to prevent accidents and reduce their effects if one should occur:

1. A system to quickly shut down a reactor and stop the fission chain reaction.

2. Numerous systems to control reactor pressure and to continue cooling the reactor fuel - that is,
A boiling water reactor sends steam from the reactor directly to the turbine generator to produce electricity. After passing through the turbine, the steam is cooled, becoming water again. This water is then pumped back to the reactor to be reheated. 


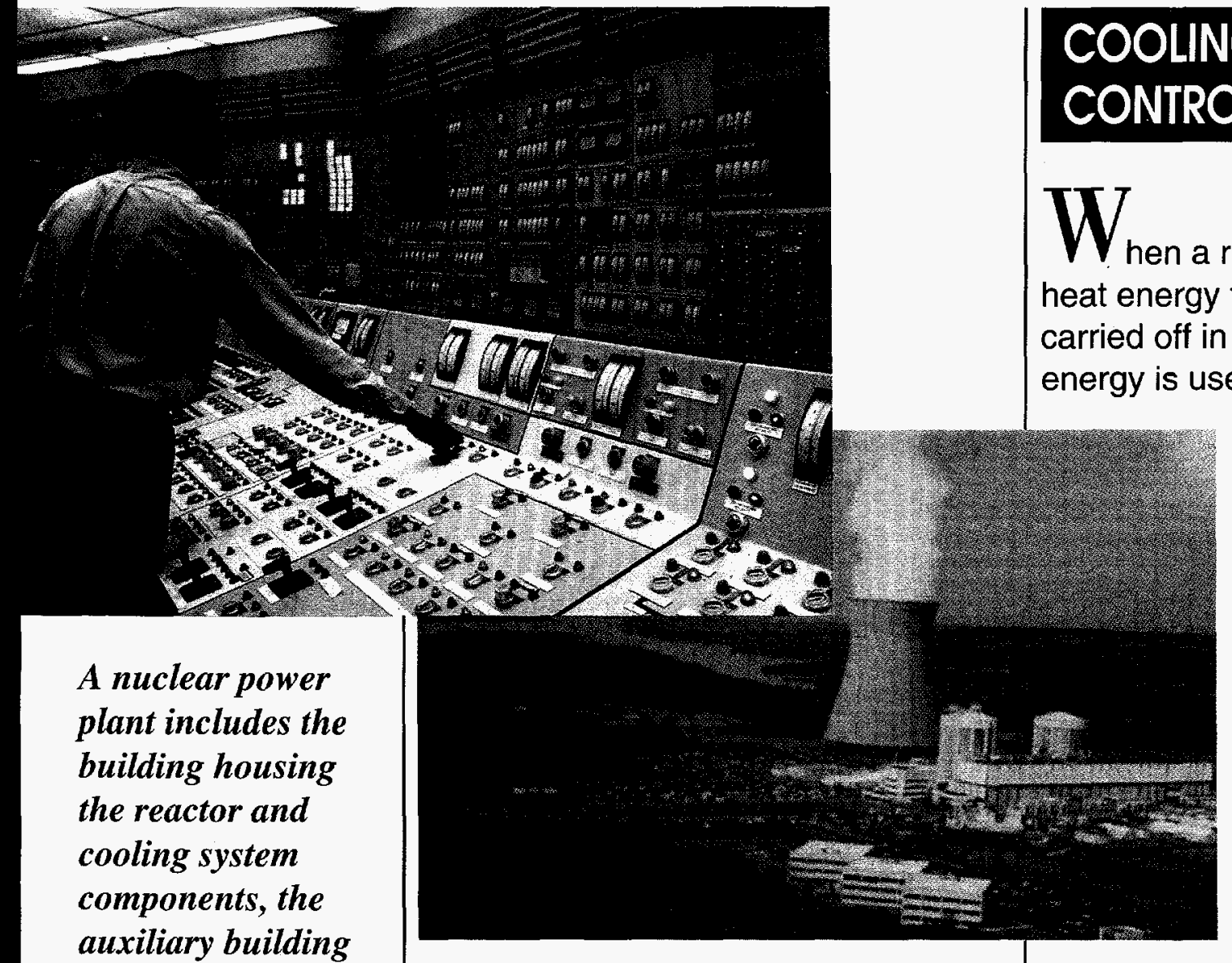

to carry away the heat that continues to be generated even after the reactor is shut down.

3. Electrical, control, and instrument systems for safety systems and for monitoring reactor conditions.

4. System of barriers to contain radioactivity if it should escape from the reactor fuel in an accident.

\section{SHUTDOWN SYSTEMS}

turbine. Water for this condensing function comes from a river, lake or ocean and does not pass through the reactor itself.

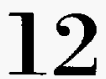

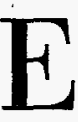
the control rods into the reactor core within seconds to stop the fission reaction. This immediate shutdown called a reactor "scram" or reactor "trip" - can be triggered by a reactor operator or by automatic controls that protect the reactor from any unusual conditions in the plant. passes after the reactor shutdown, the amount of heat produced in the fuel in the reactor core decreases. Continued cooling of the fuel remains necessary, however. Both normal cooling systems and emergency cooling systems are available. Each system has at least two parallel parts so that if one fails, the other part would still be available to continue to cool the reactor.

The emergency core cooling system (ECCS) consists of pumps and valves and pipes that are independent of the normal cooling system. The ECCS contains equipment that can pump at high pressure to inject water into the reactor when the pressure inside is at the high levels maintained during operation. In addition, low pressure systems pump water at lower pressures, such as those that might occur if a cooling water pipe broke and allowed pressure inside the reactor to drop. 
The reactor systems also contain valves that can be opened to reduce pressure by releasing steam. These relief valves open automatically if pressure gets too high in the reactor system. Some of the valves can be opened using controls in the reactor control room. These pressure-reduction systems can also be used to reduce reactor pressure so that the low pressure cooling systems can function.

\section{SAFETY SYSTEM POWER}

\section{M} powered by electricity, although some pumps do use steam to drive them in order to have an alternative source of power. Because of this reliance on electrical power, nuclear plants are required to have multiple sources of electricity.

A nuclear plant uses a portion of the power it generates to run plant equipment. A plant also must have at least two connections to the utility's electrical distribution system so that it can immediately shift to offsite power sources if a shutdown occurs. Should there be a failure in the offsite power connections, each plant has emergency diesel generators with sufficient capacity to supply electricity to the critical safety systems.

The control and instrument systems normally use direct current (DC) electricity, the kind of power found in batteries. For these systems, large banks of batteries provide DC power if there is an interruption in the normal sources of electricity.

\section{CONTAINING RADIOACTIVITY}

$\mathrm{N}$ principal barriers to prevent the release of radioactivity - the sealed fuel rods, the reactor vessel and associated components, and the structure housing the reactor, called the reactor containment.

A serious reactor accident could damage the fuel rods, which form the first barrier, if adequate cooling does not occur. Overheated fuel rods could leak or break apart and eventually melt. Possible damage to the reactor cooling system piping could breach the second barrier.

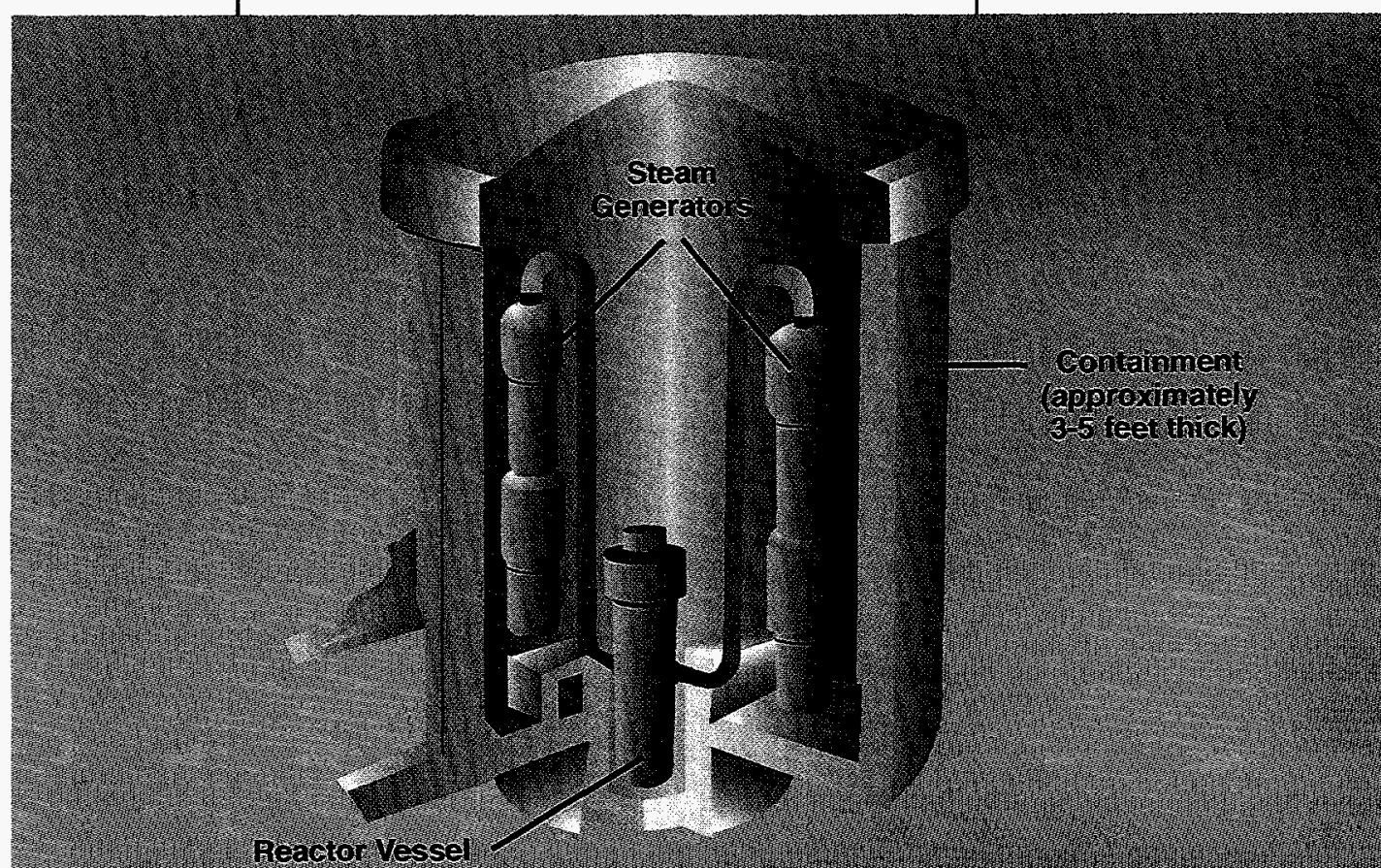

Example of a PWR Containnent

\section{The reactor}

containment is a sealed reinforced concrete and steel structure which surrounds the reactor. It is designed to contain radioactive gases that might be released by a pipe break or other major reactor accident. 
Even with the failure of these first two barriers, the reactor containment is designed to hold radioactive material that might otherwise be released to the outside environment. One type of reactor containment is a large cylinder-shaped building made out of reinforced concrete with a steel lining. It is designed to withstand the pressures that might build up inside as steam and gases escape from the reactor during an accident. Another type of containment, called a pressure suppression containment, has a large water-filled pool to cool the steam and reduce the pressure buildup in the containment.

The NRC requires that the reactor containment be periodically tested to show it meets requirements to prevent leakage from inside the structure.

Although reactor containments were designed to cope with many types of serious reactor accidents, they may not withstand the conditions that result from an extremely unlikely accident in which all cooling capability is lost in the reactor. Under these circumstances, the energy produced by the radioactivity remaining in the fuel could cause the fuel to melt. Melting of the fuel could eventually lead to a pressure buildup in the containment that could cause radioactive gases to leak through seals and gaskets around the containment.

The molten fuel could also damage the concrete base of the containment, leading to a possible release of radioactivity. Even in these cases, however, most of the long-term hazardous radioactive material would remain inside the containment structure.

In the only major commercial power reactor accident in the United States, the Three Mile Island accident in 1979, there was extensive fuel damage. Radioactive gases and contaminated cooling water filled the containment.
Although some radioactivity was released to the atmosphere by an indirect route, the containment itself performed as designed and kept the radioactivity safely bottled up inside. The effectiveness of the containment was the major factor in preventing the release of large amounts of radioactive materials to the environment.

In 1986 a much more serious accident occurred at Chornobyl in the former Soviet Union. The reactor was very different from those used in the United States. The plant had no containment system like that of U.S. plants. The Chornobyl accident severely damaged the reactor core, releasing large quantities of radioactivity to the environment. Radioactive material was deposited in nearby countries, and radioactivity was detectable at very low levels in the United States.

\section{WHAT IF?}

A Ithough a major reactor accident is unlikely and each plant is equipped with safety systems to prevent or cope with an accident, additional measures help protect public heath and safety.

The first is special training given to the reactor operators in the handling of emergency situations. One of the lessons learned as a result of the Three Mile Island accident was that reactor operators needed to practice how they would handle emergencies. Detailed emergency operating procedures have been prepared and the operators have been trained to use them. In addition, most nuclear power plants use computer-based simulators for training in both routine and abnormal situations. These simulators are laid out just like the plant's control room with all of the controls and instrumentation. Comput- 

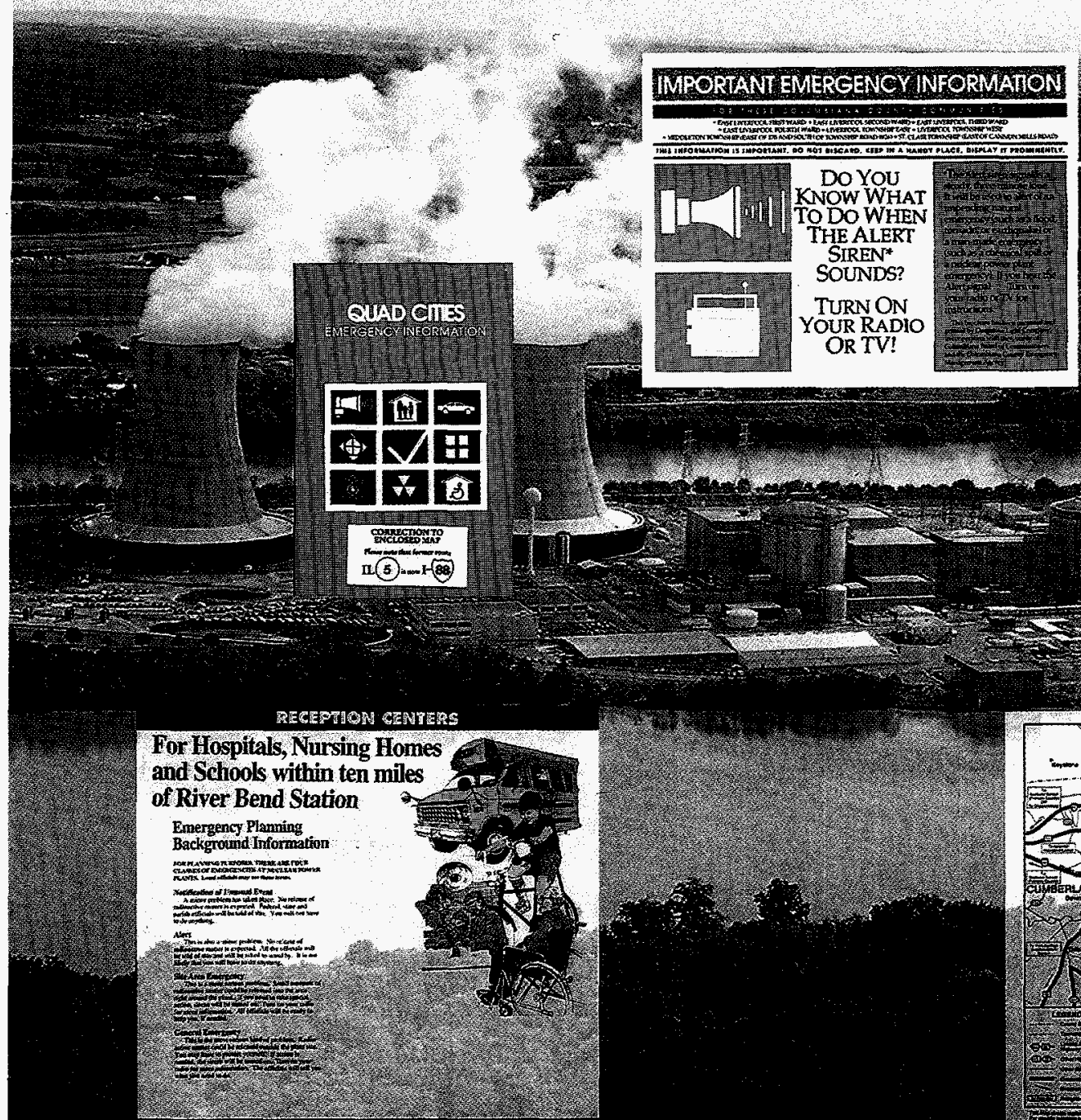

BYRON
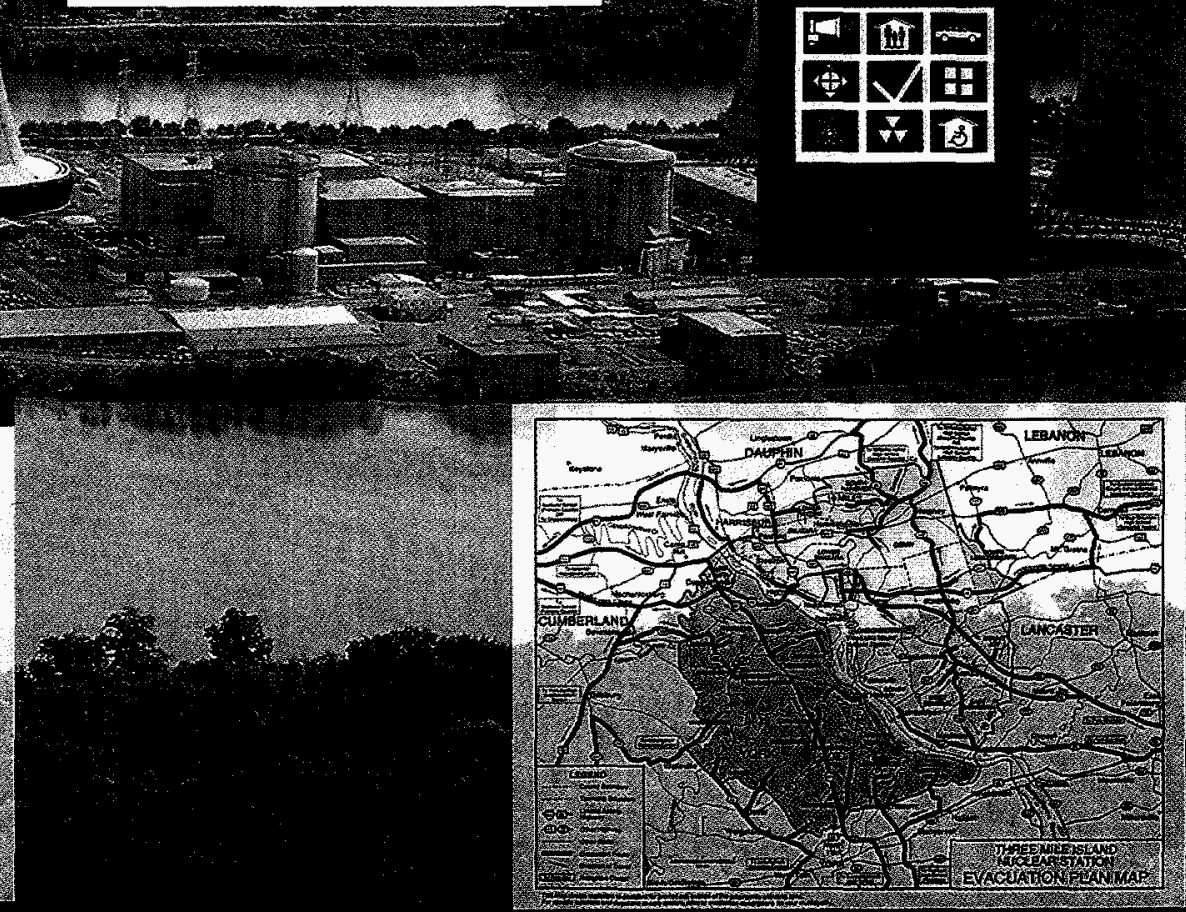

ers let the operators practice dealing with emergencies as they occur in the simulator's control room.

The Three Mile Island accident also pointed out the need for improved planning by Federal, State, and local governments to deal with possible reactor accidents. The NRC now requires that emergency plans be prepared for evacuation or other actions to protect the residents in the vicinity of nuclear plants. These plans usually cover an area about 10 miles in all directions around each nuclear plant. The utility has its own emergency plan to notify government officials of a possible emergency and to provide them with information and recommendations. State and local governments have detailed plans for sheltering and evacuation of residents if necessary. Federal emergency plans include Federal personnel, equipment, and resources needed to respond to a nuclear power plant accident. The NRC would closely follow the handling of an accident by a utility and investigate the causes of the accident.

These emergency plans are tested through emergency exercises that simulate a serious reactor accident. Utility personnel and government officials follow their emergency plans in gathering information, consulting with each other, and issuing instructions to the public. These emergency

\section{Each nuclear plant} has a warning system to notify nearby residents of emergency conditions. Instructions in the event of an emergency would come from State and local officials using the emergency broadcast system. 
Most of the highly radioactive spent fuel removed from civilian nuclear power plants is stored in specially designed water basins at the reactor sites. When a Federal high-level waste site becomes available, the used fuel will be moved there for permanent disposal. exercises sometimes include smallscale evacuation drills for schools, nursing homes, and other institutions.

The NRC must determine that there is reasonable assurance that evacuation or other steps can be taken to protect area residents in the event of a major reactor accident. To make this determination, the NRC reviews the utility's plans, conducts inspections, and considers the assessment of State and local planning by the Federal Emergency Management Agency.

\section{NUCLEAR INSURANCE}

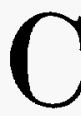
tem of "no-fault" insurance to provide liability coverage in the event of a major reactor accident. This insur- ance program, initiated under the Price-Anderson Act, combines commercial insurance and self-insurance by the nuclear industry. Large nuclear plants are required to have the maximum amount of liability insurance that is commercially available, currently $\$ 200$ million. In addition, each licensed reactor is liable for a $\$ 75.5$ million assessment to provide funds in the event of a major accident at a plant in the United States. (No reactor would be assessed more than $\$ 10$ million in any one year.)

With about 110 nuclear power plants in the United States, the combination of commercial insurance and industry self-insurance exceeds $\$ 8$ billion. This is the total liability limit for an accident under the PriceAnderson Act and no claims are required to be paid in excess of this amount. Congress, however, will consider the need for providing an additional source of funds should $\$ 8$ billion prove inadequate.

The Price-Anderson Act provides for liability insurance coverage for actual damages incurred by anyone affected by a major reactor accident. Besides the coverage for offsite public liability claims, the NRC requires that utilities maintain $\$ 1$ billion in onsite property damage insurance to provide funds to deal with cleanup of the reactor site after an accident. 
RADIOACTIVE WASTE DISPOSAL

D uring normal operations, a nuclear power plant generates two types of radioactive wastes - highlevel waste, which consists of used fuel (usually called spent fuel), and lowlevel wastes, which include contaminated equipment, filters, maintenance materials, and resins used in purifying water for the reactor cooling system. Other users of radioactive materials also generate low-level wastes.

Each type of waste is handled differently.

\section{HIGH-LEVEL WASTE}

\section{ח}

he spent fuel from nuclear power plants is stored in water-filled pools at each reactor site and at one storage facility in Illinois. Several utilities have recently begun using dry cask storage pending final disposal. In this way spent fuel is stored in heavy metal or concrete containers placed on concrete pads adjacent to the reactor facility. From one-fourth to one-third of the reactor fuel is removed and replaced during refueling. Reactors are normally refueled every 12 to 18 months.

Spent fuel is highly radioactive because it contains the fission byproducts that were created while the reactor was operating. One character- istic of radioactive material is that it decays or loses its radioactivity at a set rate. Each radioactive component has a different rate of decay called its half-life - the time it takes the material to lose half of its radioactivity. Some fission byproducts have a halflife of a few seconds; others have halflives of hundreds or thousands of years.

When fuel is first removed from the reactor, the short-lived radioactive materials are still present. But over time, these substances decay, leaving the longer-lived materials as the principal substances for disposal. These materials include cobalt-60 (5-year halflife), cesium-137 (30-year half-life), and plutonium-239 (24,400-year half-life).

Special procedures are needed in the handling of the spent fuel, since the radiation levels can be very dangerous without proper shielding. The water in the spent fuel storage pool provides cooling and adequate shielding from the radiation to protect workers
Proposed high-level waste disposal site at Yucca Mountain, Nevada

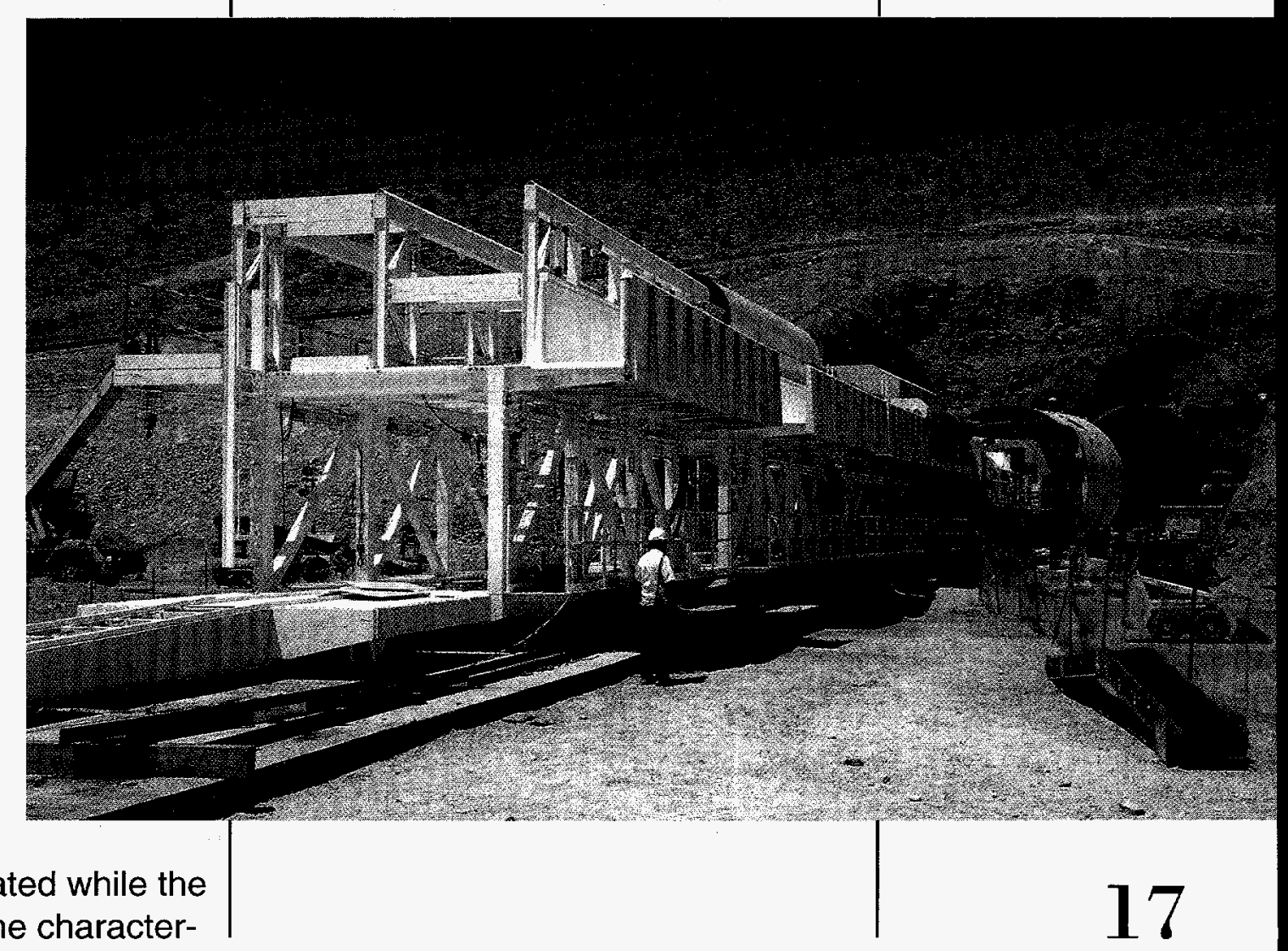


in a nuclear plant. Concrete and steel in dry casks provide adequate protection, too.

Although most of the spent fuel remains stored at individual plants, some spent fuel has been shipped to offsite interim storage facilities. One offsite storage in Illinois. These shipments have used heavily shielded shipping containers designed to withstand the conditions that might occur during a shipping accident. Spent fuel has been shipped by rail and by truck. The NRC certifies each shipping container that meets facility operates

Federal requirements, and the Department of Transportation sets the rules for actual transportation of the spent fuel.

Some of the components in spent fuel remain hazardous for a long time. Permanent disposal of spent fuel, therefore, requires a disposal facility that provides reasonable assurance that the waste will remain isolated for thousands of years.

The Department of Energy (DOE) is developing plans for a permanent disposal facility for spent fuel from nuclear power plants as well as for the high-level waste produced by the Nation's nuclear weapons production activities.

\section{Congress has directed DOE to} focus on a proposed site at Yucca Mountain in southern Nevada for this waste disposal facility. Site studies are still under way to determine if the site is adequate for long-term disposal of the high-level waste.

DOE would design, build, and operate the facility, and the NRC would regulate it. The NRC must approve the site and design for the facility and must inspect it during construction and operation.

Although some nuclear plants have adequate capacity to store the spent fuel they generate until a DOE site is available for disposal, other plants, particularly the older ones, may soon run out of storage space in their spent fuel pools. DOE and the nuclear industry are considering various options to store additional 
spent fuel, including dry storage, construction of additional offsite interim storage facilities, and techniques for storing more fuel in the existing spent fuel storage pools.

\section{LOW-LEVEL WASTE}

Jow-level radioactive waste,

whether from a nuclear power plant or from other users of radioactive material, is shipped to licensed commercial disposal facilities where it is packaged and placed in burial trenches and covered with soil. Less than half of the waste volume is from nuclear power plants; the remainder is generated by hospitals, research institutes, and other users of radioactive materials.

In 1980 Congress mandated that each State be responsible for assuring the availability of disposal capacity for commercial low-level waste produced in the State. States could provide for disposal either individually or as a group by joining together in a regional agreement. The individual States or State groups are in the process of selecting new burial sites or, in some cases, will use the facilities that have been operating.

\section{TRANSPORTATION}

$A$

bout 3 million packages of radioactive materials are shipped each year in the United States - by highway, rail, air, and water. Regulating the safety of these shipments is the joint responsibility of the U.S. Department of Transportation (DOT) and the NRC.
Through the years, commercial lowlevel radioactive waste has been buried at sites in six States -

Washington, South Carolina, Nevada, Illinois, Kentucky, and New York. Sites in the latter three States have been shut down for many years, and the

Nevada site ceased operation on the first day of 1993.

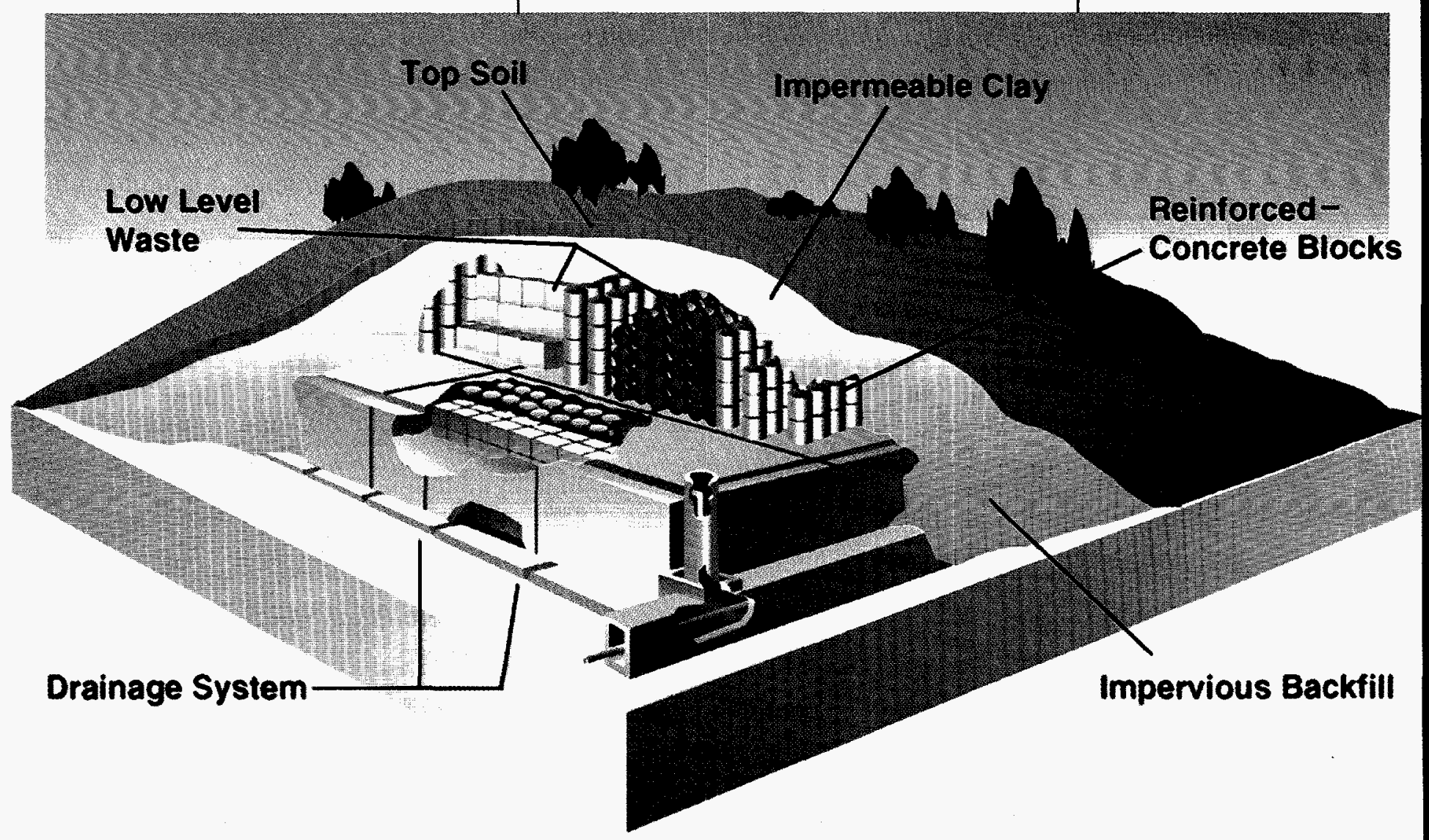


State governments are notified in advance of spent fuel shipments and those large-quantity shipments of radioactive waste requiring Type $B$ packages.

The regulatory system for transportation of radioactive materials has been successful in minimizing the safety impact from accidents involving the shipments. Few accidents have occurred involving shipments of radioactive materials (averaging less than 50 out of 3 million packages shipped annually). Only a small number of those accidents have involved any release of the radioactive contents. In these instances, radioactive contamination has been generally minor with no public safety consequences.

\section{DECOMMISSIONING}

\section{D} ecommissioning is the term used for ending the operation of a nuclear facility. Nuclear power plants are licensed for a term of 40 years. Some plants may be closed before that time elapses; others may seek an extension of the license period.

Several nuclear power plants have been decommissioned, and some others are undergoing decommissioning. The NRC has adopted extensive regulations for dealing with the technical and financial issues associated with decommissioning.

These regulations apply to nuclear power plants and to other facilities that handle radioactive materials in forms that may require cleanup procedures when the facility is closed. Careful radiation surveys must also be performed before the site can be released for other uses.

During the operating life of a nuclear power plant, many plant components associated with the reactor become radioactive, either through contamination or as a result of the radiation from the fission reaction. Therefore, care is needed in the handling of decommissioning work, and contaminated materials have to be shipped to a low-level radioactive waste disposal site for burial.

The NRC has identified two principal plans for decommissioning a nuclear power plant - immediate dismantling or safe storage for a period of 30 to 50 years followed by dismantling. A third option, called entombment, may also be available in some cases. This would involve sealing off radioactive components with concrete and steel. Entombment would require less main-
Dismantlement of the Trojan Nuclear Power Plant in Oregon.

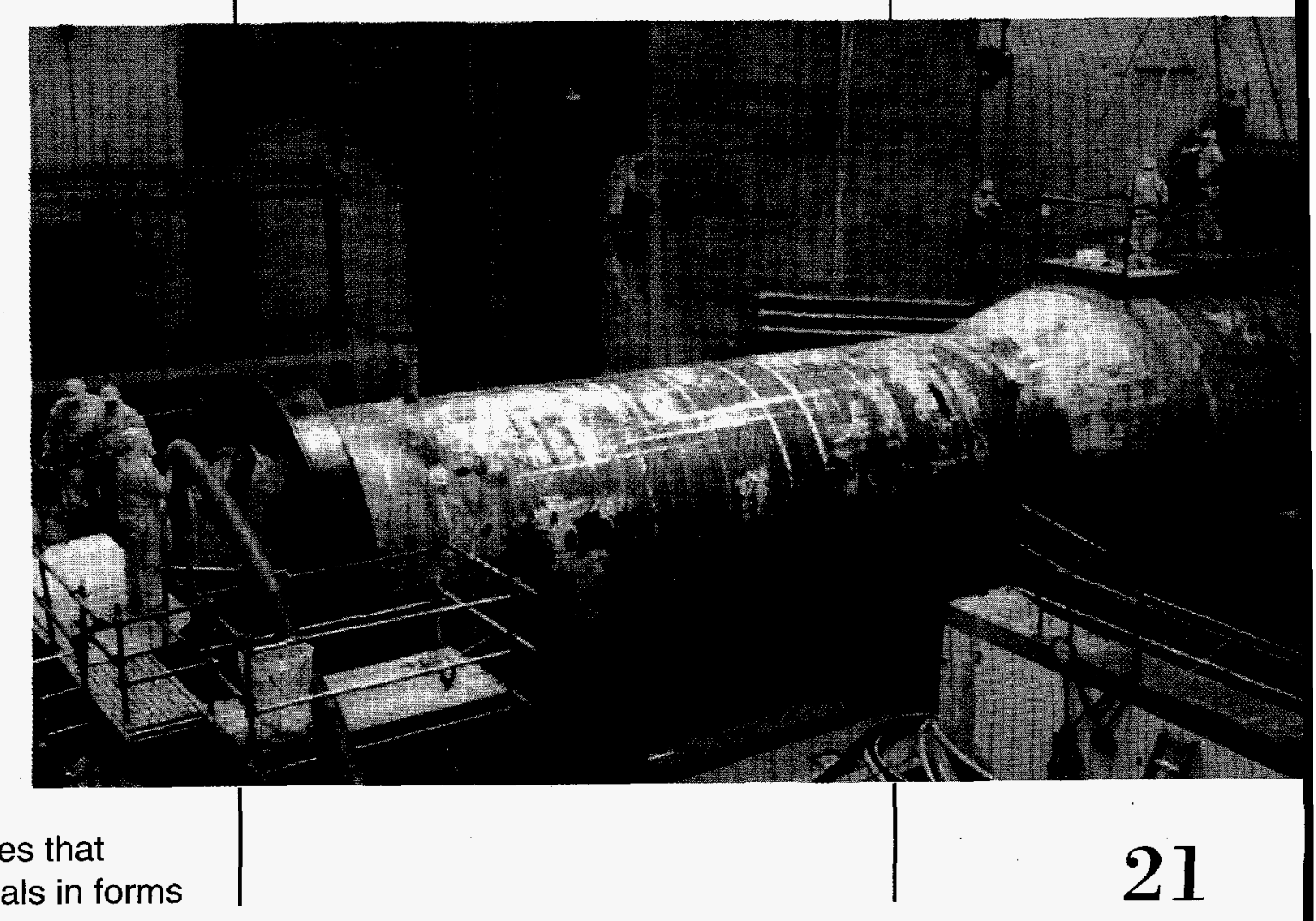


The photographs to the right show the remediation stages of the Babcock and Wilcox site in Apollo, Pa. The site formerly housed a uranium fuel processing and fabrication plant that was

decommissioned in 1995. Operations at the site ceased in 1983. Soil contaminated with uranium and other low-level waste was shipped to a disposal facility for burial. When surveys and monitoring indicate the site meets NRC release criteria, the license will be terminated and the site released for unrestricted use.

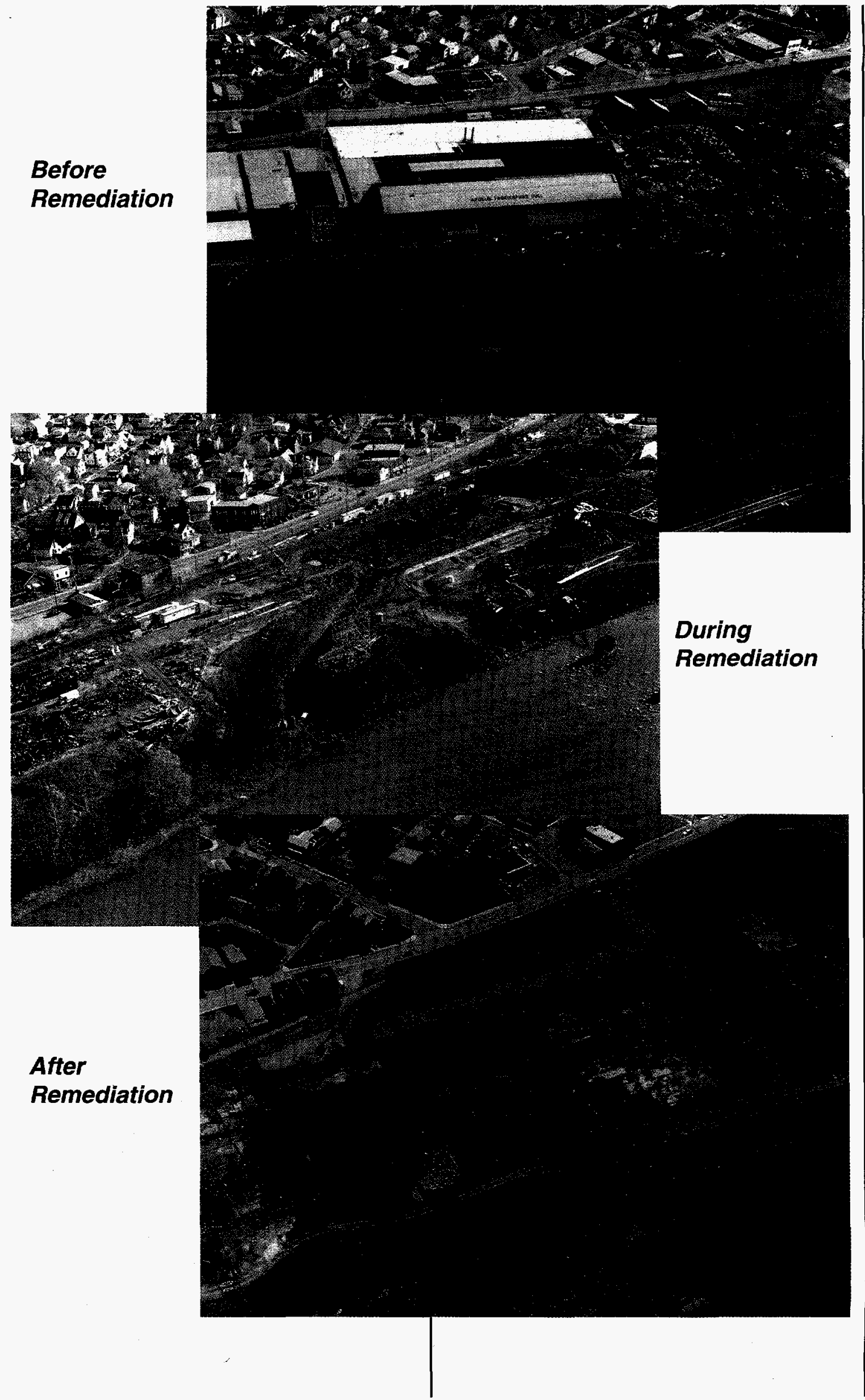


tenance and fewer security provisions than the storage option.

The storage and entombment methods allow for a reduction in the levels of radioactivity over time. NRC studies have shown that after 50 years, the volume of radioactively contaminated material would be reduced to one-tenth of the original volume as a result of radioactive decay. Delay in dismantling a plant would also result in lower radiation exposures to the workers involved.

Cost estimates for decommissioning a large nuclear plant are $\$ 300$ million or more, plus the cost of demolition of non-contaminated materials. The NRC decommissioning rules require utilities to establish funds to pay for the future decommissioning of their plants.
Similar financial procedures are also required for other types of nuclear facilities, including plants that prepare fuel for nuclear power plants or process radioactive materials.

Some facilities that previously used nuclear materials in processing or manufacturing activities require special management attention to ensure proper remediation. The NRC developed a Site Decommissioning Management Plan to compel timely cleanup of certain unusual and difficult sites, particularly those with a lot of soil contamination or with old, contaminated buildings. About 40 sites are listed in the plan. Remediation can usually be completed in four years. Afterwards, the site can be used safely for any purpose.

\title{
FOR ADDITIONAL INFORMATION, CONTACT:
}

\author{
Office of Public Affairs \\ U.S. Nuclear Regulatory Commission \\ Washington, D.C. 20555-0001 \\ 301-415-8200 \\ E-Mail: OPA@NRC.GOV \\ Internet Home Page: http://www.nrc.gov
}

\section{REGIONAL PUBLIC AFFAIRS OFFICES}

\section{Region I}

475 Allendale Road

King of Prussia, PA 19406-1415

610-337-5330

Region II

61 Forsyth Street, S.W.

Suite 23T85

Atlanta, GA 30303

404-562-4400
Region III

801 Warrenville Road

Lisle, IL 60532-4531

630-829-9663

Region IV

611 Ryan Plaza Drive

Suite 400

Arlington, TX 76011-8064

817-860-8128

Walnut Creek Field Office

1450 Maria Lane

Walnut Creek, CA 94596-5368

510-975-0346 


\section{NOTES}

24

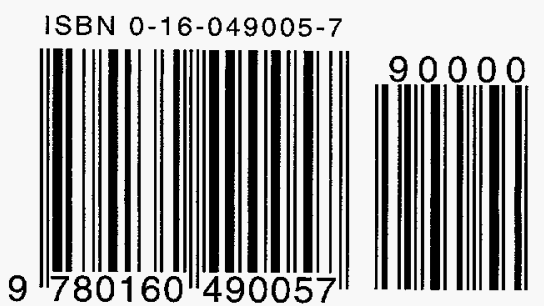

